

Review Paper

\title{
Recycling of glass waste in ceramics-part I: physical, mechanical and thermal properties
}

\author{
H. H. M. Darweesh ${ }^{1}$ \\ (c) Springer Nature Switzerland AG 2019
}

\begin{abstract}
The study concentrated on the possibility to use glass waste nanoparticles with an original ceramic batch to produce wall and floor tiles. Eight different mixtures with various ratios of glass waste nanoparticles were prepared $(0,5,10,15,20,25$, 30 and $35 \%$ having the symbols G0, G1, G2, G3, G4, G5, G6 and G7), respectively, and then fired in a temperature range of $1000-1200^{\circ} \mathrm{C}$ for $2 \mathrm{~h}$ soaking. Results showed that the water absorption decreased as the glass content increased up to $35 \%$ if fired up to $1100{ }^{\circ} \mathrm{C}$. On firing $>1100{ }^{\circ} \mathrm{C}$, the water absorption decreased only up to $25 \%$ glass (G5), and then increased with $\mathrm{G} 6$ and $\mathrm{G} 7$. The bulk density of all batches increased up to $1100^{\circ} \mathrm{C}$. On firing $>1100^{\circ} \mathrm{C}$, the bulk density increased only up to up to $25 \%$ glass, and then decreased with further increase of glass content. The mechanical properties in terms of flexural and crushing strengths were displayed the same trend of bulk density. The dry shrinkage recorded zero reading, i.e. it was unchanged, while the firing shrinkage was slightly increased with both glass content and firing temperature. The experimental results revealed that the glass contributes to improve thermal, physical and mechanical properties as well as microstructure of the prepared samples containing up to $25 \mathrm{wt} \%$ of glass fired at $1150^{\circ} \mathrm{C}$. The addition of high amounts of glass ( $>25 \mathrm{wt} \%$ ) into the ceramic body is undesirable due to its adverse action on physical and mechanical properties of the fired products and moreover, the external appearance of the ceramic units are too bad. The dry shrinkage was unchanged, but the firing shrinkage was increased with both temperature and glass content. The coefficient of linear thermal expansion decreased with glass content.
\end{abstract}

Keywords Clay - Glass waste $\cdot$ Water absorption $\cdot$ Bulk density $\cdot$ Flexural $\cdot$ Crushing $\cdot$ Strength $\cdot$ Shrinkage $\cdot$ Expansion

\section{Introduction}

\subsection{Scope of the problem}

Nanomaterials have extremely very small size of at least one dimension $\leq 100 \mathrm{~nm}$. Nanomaterials have applications in the field of nanotechnology, and displayed different physical and chemical characteristics [1, 2]. The increase in the various solid waste residues in the cities particularly those do not decompose easily neither in nature, nor by weathering factors for thousands of years such as wastes of glass bottle that created the growth of both ground and air populations. The recycling of these wastes is an important environmental and economical alternative solution [3-12]. This will make that it is possible to reach some important objectives related to the storage of wastes, conserving limited supplies of natural raw materials and consequently, safeguarding the environment $[3,4]$. The wastes of glass bottles are composed of high amount of $\mathrm{SiO}_{2}(70-74) \%$ and a reasonable amount of alkaline earth oxides: $\mathrm{Na}_{2} \mathrm{O}(12-16) \%, \mathrm{CaO}(5-11) \%$ and $\mathrm{MgO}(1-3) \%$ [13-15]. In Egypt, there are huge quantities of waste glass bottles of several shapes and sizes. This evidently causes an environmental problem like as the ground pollution. Therefore, it is very necessary to solve this serious problem through scientific researches that could use these priceless

$\triangle$ H. H. M. Darweesh, hassandarweesh2000@yahoo.com| ${ }^{1}$ Refractories, Ceramics and Building Materials Department, National Research Centre, Cairo, Egypt.

SN Applied Sciences (2019) 1:1274 | https://doi.org/10.1007/s42452-019-1304-8 
waste materials in traditional ceramics like as wall and/or floor tiles, table wares or porcelain stoneware tiles. These may be used for out and/or indoor applications. Thus, the glass waste can act as inert component in total replacement of quartz sand, and also can act as fluxing agent at the expense of feldspar totally. Clay is a product which is coming from the decomposition of granite rocks that is represented of about $75 \%$ of the earth's crust, and it is essentially composed of alumina $\left(\mathrm{Al}_{2} \mathrm{O}_{3}\right)$ and silica $\left(\mathrm{SiO}_{2}\right)$, i.e. these two minerals are of the major constituents of clay $[13,14]$. Clay is known to provide the plasticity of the whole mixture. Granite often decomposes into feldspar, the most common mineral, which is composed of $\mathrm{Al}_{2} \mathrm{O}_{3}$, $\mathrm{SiO}_{2}$, and a flux of an alkaline nature e.g. sodium, potassium, lithium and calcium. The fluxing agents as feldspar, talc, pyrophyllite, etc. could produce the liquid or glassy phase during sintering and the inert material (quartz) favours the dimension control of the product after firing $[10,16,17]$. The flux is somewhat soluble, and over long periods of weathering is carried off by moisture [14, 15, 18]. Due to its mineralogical and chemical composition, waste glass shows fluxing properties and as a result, can run in replacement of fluxing agent used in traditional ceramic particularly feldspar. Several works have been published for this purpose [17-21].

\subsection{Objectives of the study}

The main objective of the current research article is to study the feasibility of using glass waste with a traditional ceramic batch made from clay, feldspar, limestone and quartz in the elaboration of ceramic units. In the first part, the effect of firing temperature as well as content of glass waste in the traditional ceramic batch will be investigated and discussed in terms of physical and mechanical properties as well as thermal behaviour.

\section{Experimental and methods}

\subsection{Raw materials}

The clay sample (TC) was taken from Toshka region which is located on latitude $20^{\circ} 30^{\prime} \mathrm{N}$ and longitude $31^{\circ} 53^{\prime} \mathrm{E}$ at $250 \mathrm{~km}$ south of Aswan. It was related to the Upper Cretaceous age. The selected clay deposit is belonging to ElDakhla Shale Formation (Fig. 1).

About $10 \mathrm{~kg}$ clay was collected from the 85th km north of Aswan/Abu-Semple asphaltic road. It is a dark yellowish grey. The clay sample was first well dried in an open air for 3 days and also in a suitable furnace at $105^{\circ} \mathrm{C}$ for another 3 days, then crushed, ground and quartered to have a representative sample which was fine ground to

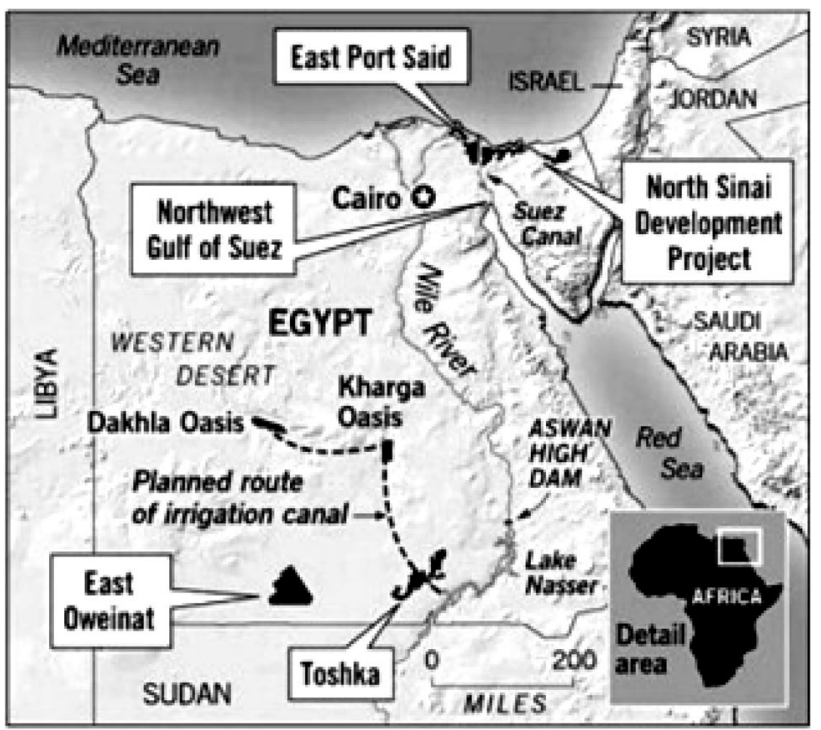

Fig. 1 Location of Toshka area from which the clay sample was taken

pass a 200 mesh sieve using a suitable agate mortar. Feldspar (F), quartz (Q) from El-Hekma firm, limestone (LS) from Samalout district and a waste of broken fired ceramic known as Grog (GG) were obtained from the Arab Ceramic Company which is commercially known as Aracemco, Egypt. The chemical analysis using the $\mathrm{X}$-ray fluorescence technique (XRF) and the particle size distribution of the starting raw materials are shown in Tables 1 and 2, respectively. Figure 2 demonstrates the DTA-TGA thermograms of clay sample. The endothermic peak at the temperature range of $700-900^{\circ} \mathrm{C}$ is due to the calcination of limestone. The two endothermic peaks at the temperature range $100-120^{\circ} \mathrm{C}$ and $500-600^{\circ} \mathrm{C}$ are due to the evaporation of the absorbed and structural or hygroscopic water, respectively. The endothermic peak at the temperature range 500-600 ${ }^{\circ} \mathrm{C}$ is due to the conversion of kaolinite $\left(\mathrm{AS}_{2} \mathrm{H}_{2}\right)$ to metakaolin $\left(\mathrm{A}_{2} \mathrm{~S}_{2}\right)$, which in turn is converted to mullite phase $\left(\mathrm{A}_{2} \mathrm{~S}_{2}\right)$ at $980^{\circ} \mathrm{C}$ as follows:

$\mathrm{Al}_{2} \mathrm{O}_{3} \cdot 2 \mathrm{SiO}_{2} \cdot 2 \mathrm{H}_{2} \mathrm{O} \rightarrow \mathrm{Al}_{2} \mathrm{O}_{3} \cdot 2 \mathrm{SiO}_{2} \rightarrow 3 \mathrm{Al}_{2} \mathrm{O}_{3} \cdot 2 \mathrm{SiO}_{2}$

The XRD analysis of the used clay and glass waste samples are shown in Fig. 3 Clay is essentially composed of kaoline, quartz, illite and gibbsite, whereas that of the waste glass is composed mainly of quartz and minor traces of other oxides.

\subsection{Preparation and methods}

The suggested base ceramic batch was prepared from $50 \%$ Clay (TC), 20\% feldspar (F), 15\% quartz (Q), 10\% limestone (LS) and $5 \%$ grog (GG). The base batch composition 
Table 1 Chemical analysis of the starting ceramic raw materials, wt $\%$

\begin{tabular}{lllllll}
\hline Oxides & Materials & & & & & \\
\cline { 2 - 6 } & $\mathrm{TC}$ & $\mathrm{F}$ & $\mathrm{Q}$ & $\mathrm{LS}$ & $\mathrm{GG}$ & $\mathrm{GW}$ \\
\hline $\mathrm{SiO}_{2}$ & 51.47 & 75.37 & 93.63 & 0.08 & 61.73 & 70.31 \\
$\mathrm{Al}_{2} \mathrm{O}_{3}$ & 28.78 & 13.62 & 3.64 & 0.02 & 28.11 & 2.46 \\
$\mathrm{Fe}_{2} \mathrm{O}_{3}$ & 3.99 & 0.41 & 0.08 & 0.03 & 7.50 & 0.26 \\
$\mathrm{CaO}$ & 0.61 & 0.53 & 0.18 & 56.83 & 0.91 & 8.69 \\
$\mathrm{MgO}$ & 1.38 & - & - & 0.11 & 0.37 & 3.62 \\
$\mathrm{MnO}$ & 0.04 & 0.03 & 0.02 & - & - & 0.02 \\
$\mathrm{Na}$ & 1.15 & 3.44 & 0.17 & 0.13 & 1.24 & 13.52 \\
$\mathrm{~K}_{2} \mathrm{O}$ & 1.19 & 5.84 & 0.14 & 0.06 & 1.39 & 1.06 \\
$\mathrm{SO}_{3}$ & - & 0.02 & 0.14 & 0.02 & - & - \\
$\mathrm{TiO}_{2}$ & 1.14 & 0.05 & 0.16 & 0.01 & 1.57 & 0.12 \\
$\mathrm{P}_{2} \mathrm{O}_{5}$ & 0.53 & - & - & - & - & 0.02 \\
$\mathrm{Cl}^{-}$ & - & 0.02 & 0.06 & 0.08 & - & - \\
$\mathrm{Cr}_{2} \mathrm{O}_{3}$ & - & - & - & - & - & 0.01 \\
$\mathrm{LOI}^{\mathrm{Total}}$ & 9.72 & 0.67 & 1.78 & 42.63 & - & - \\
\hline
\end{tabular}

Table 2 The grain size distribution of the used raw materials, wt $\%$

\begin{tabular}{llllll}
\hline Particle size (wt\%) & \multicolumn{2}{l}{ Materials } & & & \\
\cline { 2 - 6 } & $\begin{array}{l}\text { Toshka clay } \\
\text { sample (TC) }\end{array}$ & Feldspar (F) & Quartz (Q) & Limestone (LS) & Waste glass (GG) \\
\hline$>63$ & 1.43 & 0.17 & 0.13 & 0.13 & 0.19 \\
63 to 16 & 1.68 & 0.13 & 0.15 & 0.18 & 0.28 \\
-16 to 8 & 2.96 & 0.89 & 0.12 & 0.18 & 0.12 \\
-8 to 2 & 9.14 & 10.43 & 4.58 & 1.17 & 6.46 \\
$<2$ & 84.79 & 88.38 & 95.12 & 98.34 & 92.95 \\
Total (\%) & 100 & 100 & 100 & 100 & 100 \\
\hline
\end{tabular}

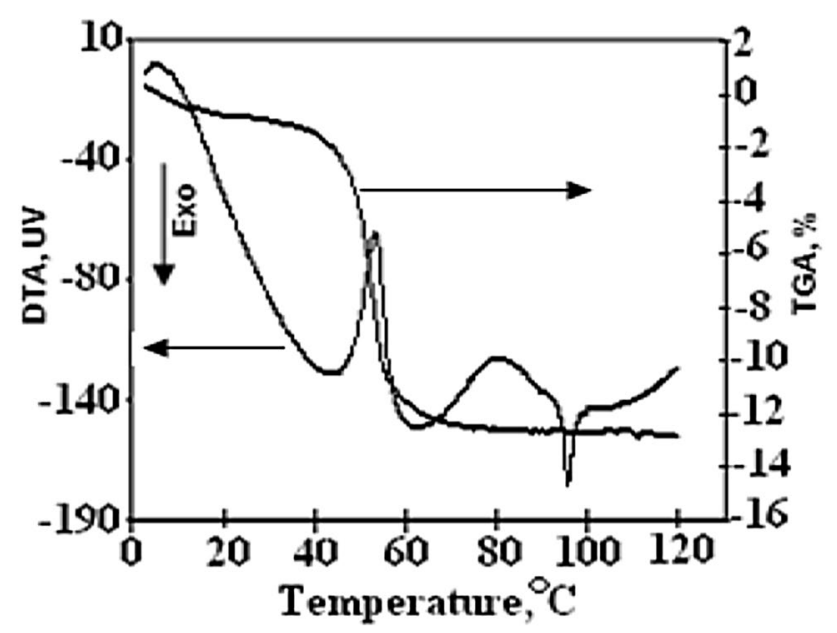

Fig. 2 The DTA/TGA thermograms of the clay sample

was well mixed in an agate ball mill for $1 \mathrm{~h}$ using the wet method, let to dry and thoroughly crushed and ground well again to pass through 200 mesh sieve to be the stock

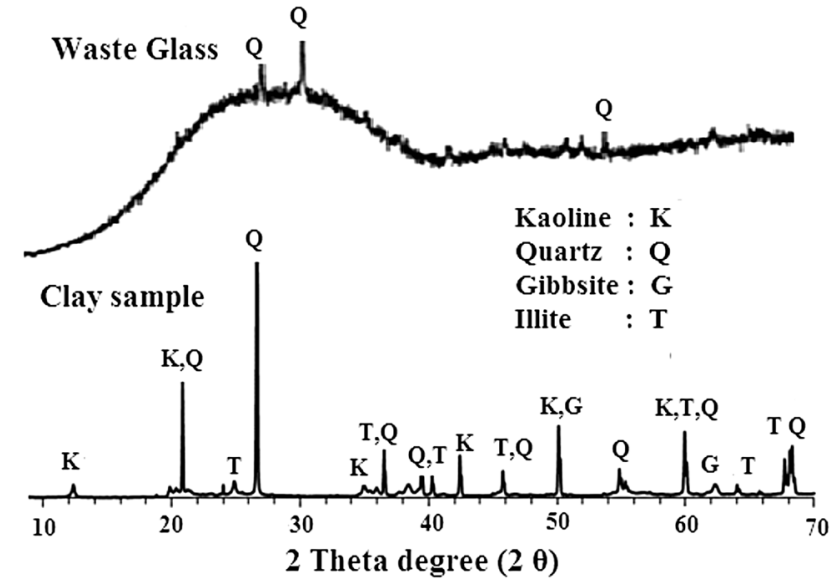

Fig. 3 The XRD patterns of the Toshka clay sample and waste glass powder

base ceramic tile batch. Eight batches from the base batch (BB) and glass waste (GW) were prepared as 100:0, 95:5, $90: 10,85: 15,80: 20,75: 25,70: 30$ and $65: 35$ mass $\%$ having 
the symbols G0, G1, G2, G3, G4, G5, G6 and G7, respectively. The batches were mixed well in agate ball mill using 3-5 porcelain balls for $2 \mathrm{~h}$, dried at $105^{\circ} \mathrm{C}$ for 3 days and then let to pass through a 200 mesh sieve to obtain the same homogeneity of all batches. Five disc-shaped samples of $1 \mathrm{~cm}$ diameter and $1 \mathrm{~cm}$ thickness were prepared for the physical properties in terms of water absorption (WA), bulk density (BD) and apparent porosity (AP). Another five rod-shaped samples of $1 \times 1 \times 7 \mathrm{~cm}^{3}$ for dry and firing shrinkage, thermal expansion and bending or flexural strength. Also, five cylindrical shaped samples of $1 \mathrm{~cm}$ diameter and $3 \mathrm{~cm}$ height for crushing strength were prepared. The molding of specimens were carried out under a shaping pressure of $20 \mathrm{KN} / \mathrm{mm}^{2}$ using water as a binder. After demoulding, the samples were let to dry in air $\left(23 \pm 2^{\circ} \mathrm{C}\right)$ for $2-3$ days, and then dried to a constant weight at $105^{\circ} \mathrm{C}$ in a suitable oven to ensure the complete elimination of the free water and to avoid the cracks during firing. The firing process was carried out by a slow rate furnace Mod. VECSTAR with heating rate of $5^{\circ} \mathrm{C} /$ $\mathrm{min}$. The firing temperatures were in the range of 1000 up to $1200^{\circ} \mathrm{C}$ with $1 \mathrm{~h}$ soaking time. The fired specimens were left to cool slowly over night inside the furnace to room temperature. The optimum firing temperature and the optimum content of GW of each ceramic batch were estimated.

\subsection{Densification parameters}

The ceramic or densification parameters $[22,23]$ in terms of water absorption (WA), bulk density (BD) and apparent porosity (AP) could be calculated from the following relations:

W.A, $\%=(\mathrm{W} 1-\mathrm{W} 2) /(\mathrm{W} 3) \times 100$

B.D, $\mathrm{g} / \mathrm{cm}^{3}=(\mathrm{W} 3) /(\mathrm{W} 1-\mathrm{W} 2)$

$$
\text { A.P, } \%=(\mathrm{W} 1-\mathrm{W} 3) /(\mathrm{W} 1-\mathrm{W} 2) \times 100
$$

where $\mathrm{W} 1$ is the saturated weight, $\mathrm{W} 2$ is the suspended or submerged weight and W3 is the dry weight, respectively. The bending or flexural strength (BS) [24-26] of the green and fired units could be carried out using a simple beam with three points loading system (Fig. 1), and it is calculated from the following equation:

B.S $=3(\mathrm{~L} \times \mathrm{S}) / 2\left(\mathrm{~W} \times \mathrm{T}^{2}\right) \mathrm{kg} \mathrm{cm}^{2} / 10.2 \mathrm{MPa}$

where B.S is the bending or flexural strength, $\mathrm{kg} / \mathrm{cm}^{2}, \mathrm{~L}$ is the beam or load of rupture, $\mathrm{kg}, \mathrm{S}$ is the Span (the distance between the two lower beams, $5 \mathrm{~cm}$ ), W is the width of the sample, $\mathrm{cm}$ and $\mathrm{T}$ is the thickness of the sample, $\mathrm{cm}$ (Fig. 4).

The crushing strength $[26,27]$ could be measured by the following relation:

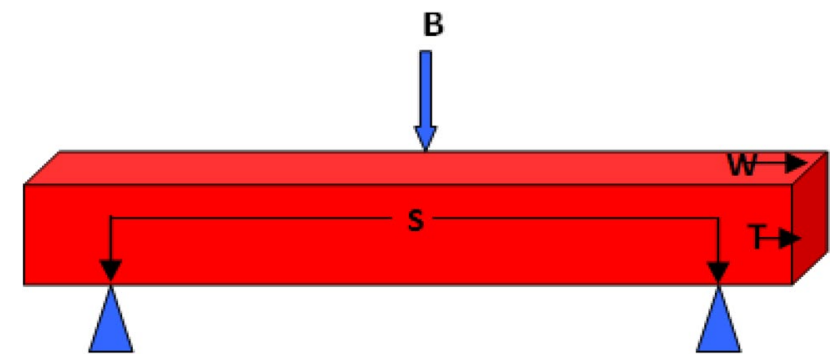

Fig. 4 Schematic diagram of the bending strength ( $B$ beam or load, $S$ spam, $T$ thickness, $W$ width)

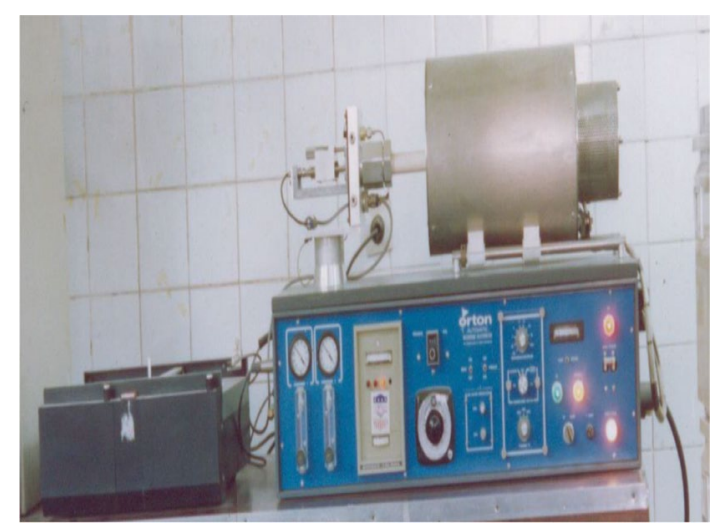

Fig. 5 Automatic Recording Orton Dilatometer for testing both firing shrinkage and thermal expansion

$\mathrm{CS}=(\mathrm{D}) /(\mathrm{L}) \times(\mathrm{w})=\mathrm{kg} / \mathrm{cm}^{2} / 10.2 \mathrm{MPa}$

where CS is the crushing strength $\mathrm{kg} / \mathrm{cm}^{2}, \mathrm{D}$ is the load $\mathrm{kg}, \mathrm{L}$ and $\mathrm{W}$ are the length and width of the samples, respectively.

\subsection{Dry and firing shrinkage as well as thermal expansion}

The tested specimens of the base batch (G0) and those containing glass waste (G1-G7) were subjected to follow up the firing shrinkage for each batch using AutomaticRecording Dilatometer of type Orton Ceramic foundation (Fig. 5). It has a self correction for both sample holder and starting room temperature. The run was carried out up to $1000^{\circ} \mathrm{C}$ with a heating rate of $5^{\circ} \mathrm{C} / \mathrm{min}$. At least 30 measurements for three representative samples of each firing temperature were taken.

Before firing, the diameter of each disc specimen was measured from more one side which was represented as (Lo). The measurements on the same disc after firing were done by the same way for each temperature interval and the average value was considered $(L)$ according 
to ASTM-Standards-C326-71 [27, 28]. The dry and firing shrinkage of the dried and fired units could be measured from the following equation:

$\mathrm{FS}, \%=(\mathrm{Lo}-\mathrm{L}) /(\mathrm{Lo}) \times 100$

The coefficient of linear thermal expansion is one of the most main thermal properties that ascertains and defines precisely the field of application of any ceramic batch composition or any ceramic product where the material that is having a low coefficient value of thermal expansion displays and exhibits a high shock resistance. The coefficient of linear thermal expansion was carried out on rectangular-shaped samples $\left(1 \times 1 \times 2.5 \mathrm{~cm}^{3}\right)$ and fired from room temperature up to $1000^{\circ} \mathrm{C}$, and was determined from the following relation:-

$\alpha=\Delta \mathrm{L} / \mathrm{Lo} \times \mathrm{L} / \Delta \mathrm{T}$

where $\Delta \mathrm{T}$ is the temperature interval of the measured values of $\Delta \mathrm{L} / \mathrm{L}$ o and $\mathrm{a}$, where $\Delta \mathrm{L} / \mathrm{L}$ o was recorded automatically by the apparatus, and then was plotted versus $T{ }^{\circ} \mathrm{C}$.

The XRF analysis is equipped by a modern wavelength dispersive Spectrometer (WD-XRF, 2005, Netherlands), provided with an integrated preparation unit including grinding, pressing and automatic bead preparation Instrument (Perl'X3, SAVOILOR S.A.S, France). The DTA-TGA thermograms of Clay sample which was carried out using NETZSCH Geratebae GmbH Selb, Bestell No. 348472c at a heating rate $10^{\circ} \mathrm{C} / \mathrm{min}$. up to $1000^{\circ} \mathrm{C}$. The XRF analysis was carried out in the National Research Centre, while the particle size distribution was achieved in Metals Institute, El-Tabine, Cairo, Egypt.

\section{Results and discussions}

\subsection{Densification parameters}

\subsubsection{Water absorption}

It is well known that the values of water absorption is considered to be an important evidence for the quality and durability of ceramic products, which accurately defines the class to which the final product belongs $[18,29]$. The results of water absorption versus the various glass contents and firing temperatures are graphically represented in Fig. 6. Generally, the values of water absorption gradually decreased with the increase of either glass content in the mixture or even firing temperature. This was taken place with all glass contents up to $35 \mathrm{wt} \%$, but only up to $1100^{\circ} \mathrm{C}$. Moreover, the values of water absorption are lower than those of the control ceramic batch (G0). This means that there is a good densification of G0-G7 when samples fired up to $1100{ }^{\circ} \mathrm{C}$. The incorporation of glass

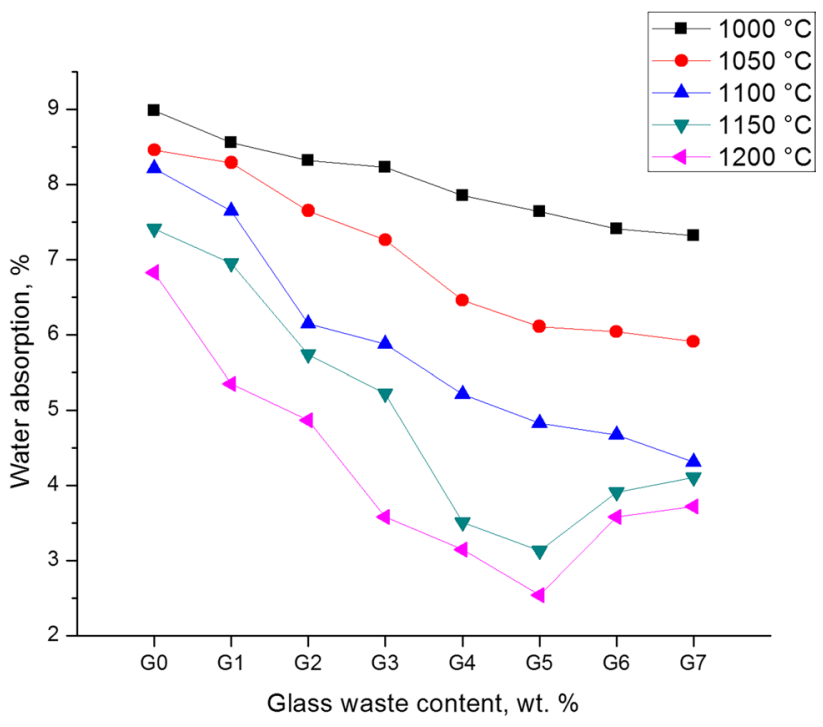

Fig. 6 Water absorption of the various ceramic batches containing glass waste at different firing temperatures

into the base or original ceramic batch seems to change the different constituents particularly alkalies in the mixture, where the amount of $\mathrm{CaO}, \mathrm{MgO}$ and $\mathrm{Na}_{2} \mathrm{O}$ increases, while that of $\mathrm{Al}_{2} \mathrm{O}_{3}$ decreased. The change in composition of samples that is coming from the partial addition of glass waste at the expense of ceramic batch (G0) could promote the variations in the viscosity of samples due to the glassy or liquid phase formed during firing. Hence, the pore system tends to decrease followed by a decrease in the rate of water absorption [30, 32].

At firing temperature $>1100^{\circ} \mathrm{C}$, the water absorption only decreased up to the batch containing $25 \mathrm{wt} \%$ glass waste (G5), and then slightly increased. This is mainly contributed to the re-increase of the outer or surface pores under high firing temperatures $[29,33,34]$. This may be due to the melting of some ingredients which tends to open the pore system of the fired samples [31, 32]. The increase of water absorption at 1150 and $1200^{\circ} \mathrm{C}$ is mainly attributed to the occurrence of surface bloating which allowed to increase or create a more pore structure of the fired samples [33-35]. Accordingly, the higher quantities of glass waste content are undesirable and so, this must be avoided [30, 32]. The base batch (G0) has a water absorption value of $6.83 \%$ at $1200{ }^{\circ} \mathrm{C}$, whereas the batch $\mathrm{G} 5$ containing 25 wt $\%$ glass waste exhibited water absorption of $2.54 \%$ at $1200{ }^{\circ} \mathrm{C}$. In accordance, as the water absorption is below $0.5 \%$, the resulting ceramic products can be used as floor tiles according to specification standard ISO 13006. On this basis, it is so recommended that with glass contents of 5 up to $25 \mathrm{wt} \%$, the optimum firing temperature is $1200^{\circ} \mathrm{C}$, but with higher glass contents (30-35 wt\%), the optimum firing temperature is $1100^{\circ} \mathrm{C}$. 




Fig. 7 Bulk density of the various ceramic batches containing glass waste at different firing temperatures

\subsubsection{Bulk density}

The variation of bulk density with firing temperature and also glass content is displayed by Fig. 7. The ceramic batches G0-G7 containing waste glass up to $35 \%$ exhibited an increase in bulk density with increasing firing temperature merely up to $1100^{\circ} \mathrm{C}$. With the increase of firing temperature $>1100^{\circ} \mathrm{C}$, the bulk density only increased up to $25 \%$ glass content and then diminished. These are in agreement with the bulk density of porcelain units in the Quartz-kaolin-feldspar system, i.e. the bulk density reaches a maximum and then drops as a pore structure could be created). This is principally contributed to the formation of new crystalline and amorphous phases and moreover to the multiple reactions between different components of the matrix during firing encouraging the thermal reactions to take place freely [36, 37]. Furthermore, as the amount of glass powder increased, the thermal reactions increased too. Consequently, a large amount of liquid phase formed fills and settles inside the pores of fired products [38]. This contributes to increase consolidation, and hence the improving in bulk density of ceramic products. For the ceramic bodies containing $30 \mathrm{wt} \%$ of glass and more (G6 and G7) and fired at $1150-1200^{\circ} \mathrm{C}$, the bulk density tends to decrease. This trend is in agreement with WA, \% behaviour, where the values increase for formulations containing higher amounts of glass (upper $25 \mathrm{wt} \%$ ) at high temperature. The densification process is slow down. This behavior is essentially justified by the creation of more pores due to the evolution of gases throughout the matrix and the acceleration of the thermal transformation of some components during firing [36-38]. Besides, the drop in bulk density of samples may be attributed to anisotropic grain growth or the effect of liquid phase sintering [39]. This was reflected negatively on the other characteristics particularly mechanical strengths. As a result, the addition of high amounts of glass ( $>25 \mathrm{wt} \%$ ) in the ceramic bodies is undesirable due to its adverse action on the physical properties of ceramic products. The densification parameters are improved with maximum firing temperature and glass content due to the fusion of glass particles forming the liquid phase that catch or stick with clay particles. Hence, water absorption is reduced to the minimum while bulk density increased due to the formation of a large amount of closed porosity. This was reflected positively on the mechanical strength which enhanced to the maximum [32].

\subsection{Mechanical properties}

\subsubsection{Flexural strength}

The flexural strength of the ceramic products containing various ratios of waste glass (G0-G7) and fired at different firing temperatures up to $1200^{\circ} \mathrm{C}$ is illustrated in Fig. 8. Generally, the flexural strength slightly increased with both glass content and also with firing temperature. The results indicated that the flexural strength of all glass batches increased piecemeal with firing temperature up to $1100^{\circ} \mathrm{C}$, but with further increase of temperature, the flexural strength enhanced only up to $25 \%$ glass content (G5) and then slightly diminished. The higher flexural strength was achieved by the fired ceramic batch incorporating $25 \%$ waste glass (G5) fired at $1200^{\circ} \mathrm{C}(21.64 \mathrm{MPa})$.

With higher firing temperature, a large amount of closed pores is formed. As a result, the flexural strength

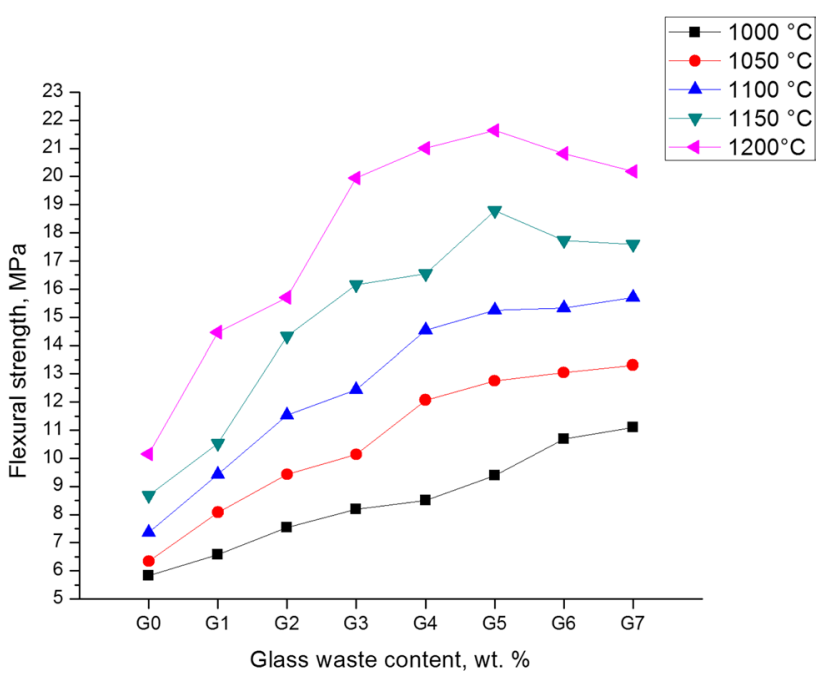

Fig. 8 Flexural strength of the various ceramic batches containing glass waste at different firing temperatures 
increased. The flexural strength of fired products was well closely related to those of water absorption and bulk density. The oxide constituents of the used wast glass like $\mathrm{CaO}$, $\mathrm{Fe}_{2} \mathrm{O}_{3}, \mathrm{Al}_{2} \mathrm{O}_{3}, \mathrm{MgO}, \mathrm{Na}_{2} \mathrm{O}$ and $\mathrm{K}_{2} \mathrm{O}$ tend to promote and create numerous thermal reactions that are resulting enough liquid phases, which in turn helps to crystallize anorthite $\left(\mathrm{CAS}_{2}\right)$ or $\mathrm{CaO} \cdot \mathrm{Al}_{2} \mathrm{O}_{3} \cdot 2 \mathrm{SiO}_{2}$, mullite $\left(\mathrm{A}_{3} \mathrm{~S}_{2}\right)$ or $3 \mathrm{Al}_{2} \mathrm{O}_{3} \cdot 2 \mathrm{SiO}_{2}$, gehlenite $\left(\mathrm{C}_{2} \mathrm{AS}\right)$ or $2 \mathrm{CaO} \cdot \mathrm{Al}_{2} \mathrm{O}_{3} \cdot \mathrm{SiO}_{2}$, wollastonite $(\beta-\mathrm{CS})$ or $\mathrm{CaO} \cdot \mathrm{SiO}_{2}$, spurrite $\left(2 \mathrm{C}_{2} \mathrm{~S} \cdot \mathrm{CaCO}_{3}\right)$ or $4 \mathrm{CaO} \cdot 2 \mathrm{SiO}_{2} \cdot 2 \mathrm{CaCO}_{3}$, cordierite $\left(\mathrm{Al}_{3}(\mathrm{Mg}, \mathrm{Fe})_{2} \cdot\left(\mathrm{AS} \cdot \mathrm{SiO}_{5} \cdot \mathrm{O}_{13}\right)\right.$ or $2 \mathrm{MgO} \cdot 2 \mathrm{Al}_{2} \mathrm{O}_{3} \cdot 5 \mathrm{SiO}_{2}$ and cristobalite to minimum. Consequently, ceramic products with a higher mechanical strength could be obtained $[36,40-42]$. It is good mention that with higher contents of glass, the samples could be deformed at higher firing temperatures $\left(1150\right.$ and $\left.1200^{\circ} \mathrm{C}\right)$ and impaired due to the formation of surface bloating of fired units so that an expansion and a complete fuse of samples have been raised. This is essentially attributed to the numerous amount of liquid phase resulting from the high quantity of glass causing the complete fusion of articles. Accordingly, the optimum ceramic products are those containing $25 \mathrm{wt} \%$ of glass (G5) fired at $1200^{\circ} \mathrm{C}$.

\subsubsection{Crushing strength}

Figure 9 shows the results of the crushing strength of the various ceramic batches containing different ratios of glass waste fired at $1000,1050,1100,1150$ and $1200^{\circ} \mathrm{C}$. As it is clear, the crushing strength increased with glass content and also with firing temperature. This is essentially due to the thermal reactions that were taken place between the constituents of ceramic batch and those of glass during firing. As the firing temperature increased, the glass

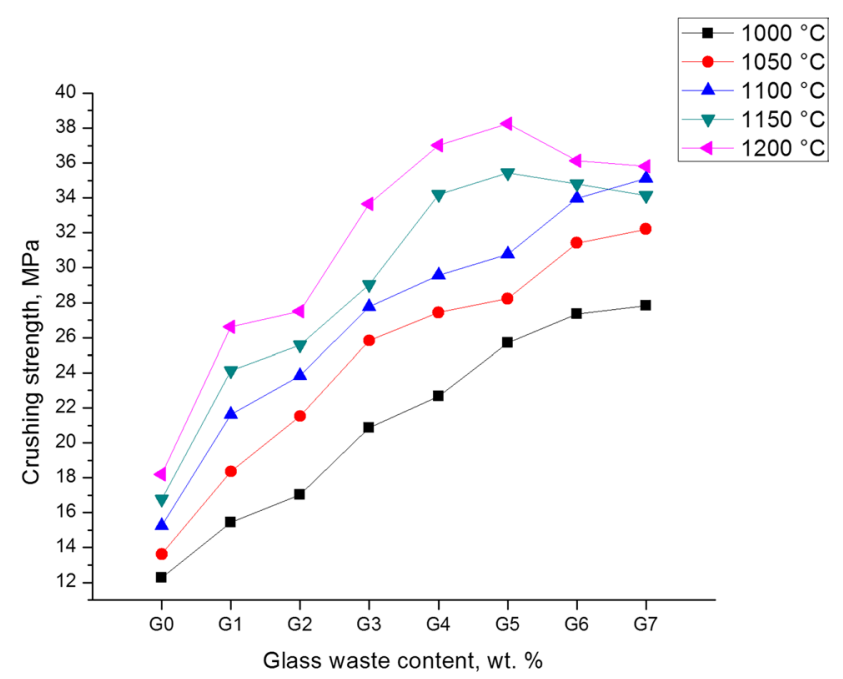

Fig. 9 Crushing strength of the various ceramic batches containing glass waste at different firing temperatures particles tend to melt gradually forming what is known as the liquid or glassy phase which helps to cement all the surrounding constituents together. This is often accompanied by a decrease in the pore structure of the fired samples and as a result their bulk densities increased. This evidently reflected positively on the crushing strength, i.e. the crushing strength increases [41-45]. On the other side, as the firing temperature enhanced up to $1100^{\circ} \mathrm{C}$, the crushing strength of all ceramic batches (GO-G7) improved and gradually enhanced slightly without any adverse effect, where the batch $\mathrm{G} 7$ containing $35 \mathrm{wt} \%$ waste glass recorded a value of $33.5 \mathrm{MPa}$ crushing strength. With the increase of firing temperature $>1100{ }^{\circ} \mathrm{C}$, the crushing strength increased only up to 25 wt $\%$ glass content (G5], but if the glass content increased more than that, the crushing strength diminished $[40,44,46,47]$. The decrease of crushing strength in this case is mainly attributed to that at high firing temperatures, the amount of the liquid or glassy phase is so higher that it migrates up to the outer surfaces of the fired units causing surface bloating, i.e. the samples appeared to be deformed, i.e. the edges, diminutions, shape and sizes of products become abnormal. On this basis, the higher amount of waste glass content in the ceramic batch is undesirable especially with higher firing temperatures $[41,42,48]$. It could be concluded that the optimum glass content is $25 \%$ fired on $1200^{\circ} \mathrm{C}$ to achieve the highest mechanical strength, or $35 \%$ fired at $1100^{\circ} \mathrm{C}$ to obtain the lower mechanical strength (Figs. 8, 9).

\subsection{Thermal characteristics}

\subsubsection{Dry and firing shrinkages}

The thermal behavior in terms of dry and firing shrinkage of the dry and fired samples containing clay, feldspar, quartz, limestone and grog during sintering is very important character in the ceramic industry (Fig. 5). This permits to control all dimensions of the resulting products and a weak linear shrinkage could be achieved $[48,49]$. The results of dry and firing shrinkage of different batches with and without glass waste at various firing temperatures up to $1200^{\circ} \mathrm{C}$ are shown in Fig. 10. The dry shrinkage of all ceramic batches containing glass waste is just equal to zero. The firing shrinkage tends to slightly increase linearly for all samples with glass waste. The same trend was displayed with all firing temperatures. The higher values of firing shrinkage mean that more thermal changes occurred between the ingredients of the ceramic batches and those of glass. This manner is supported by elevating the temperature. It may be suggested that the presence of high amount of fluxing oxides originated from feldspar and/or waste glass, helps the generation of liquid or glassy phase which fills the pore structure leading to reduce of 


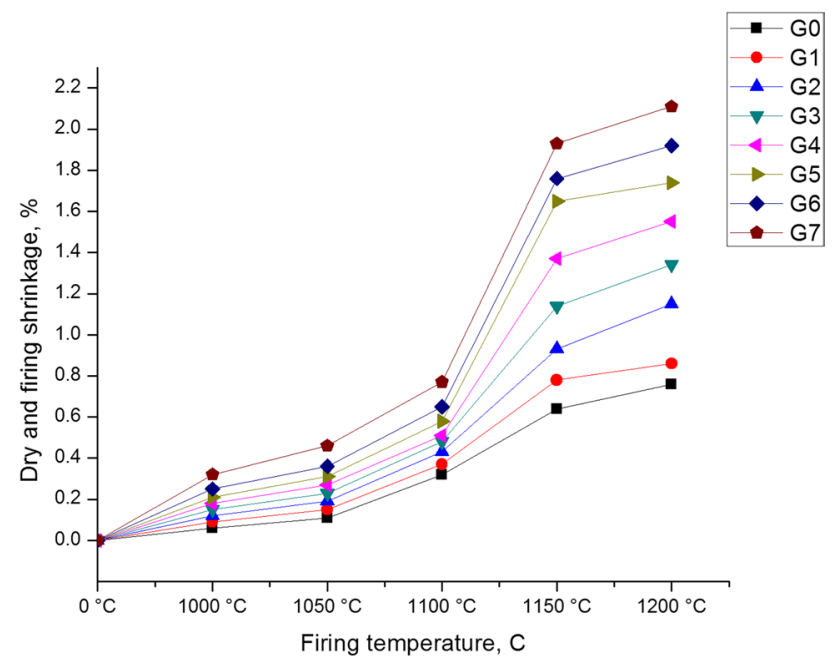

Fig. 10 Dry and firing shrinkage of the various ceramic batches containing glass waste at different firing temperatures

total porosity and promotes to bring of grains to be very close to each other, thus leading to a reduction of linear shrinkage during firing $[18,43]$.

Up to $1100^{\circ} \mathrm{C}$, a subsequent lower shrinkage value is noticed. This may be due to the decrease of the essential raw materials. But $>1100^{\circ} \mathrm{C}$, a high shrinkage was observed. Meanwhile, some products were about to deformed due to starting fusion or melting, and start to spread, impairing the determination of firing shrinkage. This evidently indicates a case of an over firing [18, 47-50]. The use of glass powder causes a formation of the liquid phase, with a low viscosity, which reduces with the increase in glass content. Hence, the lower shrinkage is favored and desired. Based on these results, the optimum amount of glass was selected to be $25 \mathrm{wt} \%$.

\subsubsection{Thermal expansion}

The results of linear thermal expansion of the various ceramic batches (G0-G7) are shown in Fig. 11 to throw light on the behaviour of samples during firing, where all samples were displayed the same trend. The firing cycle of the green samples started with the evaporation of any moisture content left in the samples after drying and also any hygroscopic moisture that picked up from the atmosphere were also driven off at $300^{\circ} \mathrm{C}$. All samples showed a gradual rapid expansion in the early stages of heating $\left(150-500^{\circ} \mathrm{C}\right)$, and then followed by a small variation at $555-665^{\circ} \mathrm{C}$. This was accompanied by a stepwise shrinkage at $800-950^{\circ} \mathrm{C}$ depending on the glass content. Moreover, it was followed by another expansion step till reached its maximum at $1060-1120^{\circ} \mathrm{C}$. This was followed by a rapid expansion to reach zero linear variation

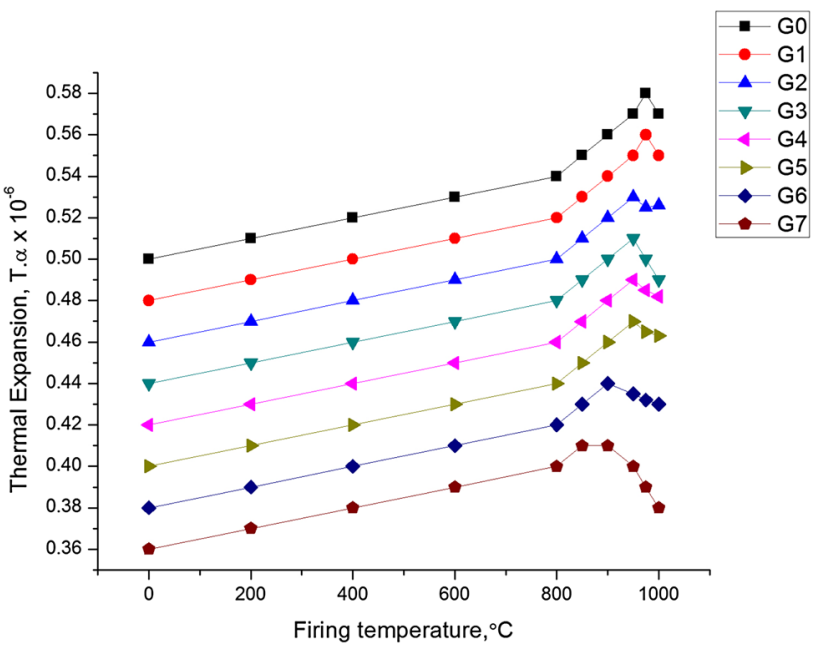

Fig. 11 Thermal expansion of the various ceramic batches containing glass waste at different firing temperatures

with all samples. At $500-650{ }^{\circ} \mathrm{C}$, the clay minerals begin to decompose and dehydroxylation occurred to form metakaolin $\left(\mathrm{Al}_{2} \mathrm{O}_{3} \cdot 2 \mathrm{SiO}_{2}\right)$, which was proceeded up to $850{ }^{\circ} \mathrm{C}$ to produce mullite phase $\left(3 \mathrm{Al}_{2} \mathrm{O}_{3} \cdot 2 \mathrm{SiO}_{2}\right)$ due to Eq. 1. At $500-650^{\circ} \mathrm{C}$, some crystalline changes occurred due to a- $\beta$-quartz transformation due to Eq. 9, which created an expansion [51, 52].

$\beta-\mathrm{SiO}_{2} \rightarrow \alpha-\mathrm{SiO}_{2}$

At $800^{\circ} \mathrm{C}$, the organic matter existed in the raw materials were burned off with the evolution of $\mathrm{CO}_{2} \uparrow$, followed by the decomposition of $\mathrm{CaCO}_{3}$ into $\mathrm{CaO}$ and $\mathrm{CO}_{2} \uparrow$ as follows:

$$
\mathrm{CaCO}_{3} \rightarrow \mathrm{CaO} \text { and } \mathrm{CO}_{2} \uparrow
$$

In presence of mullite, the thermal reactions could be enhanced and some calcium-rich phases like anorthite, gehlenite, wollastonite, spurrite and cordierite were formed [38, 52-54]. Anorthite $\left(\mathrm{CaO} \cdot \mathrm{Al}_{2} \mathrm{O}_{3} \cdot 2 \mathrm{SiO}_{2}\right)$ could be formed in two ways; either due to the thermal reactions of metakaolin with $\mathrm{CaO}$ (Eq. 11), or due to the reaction of mullite with the excess of $\mathrm{CaO}$ in presence of quartz (Eq. 12).

$\mathrm{SiO}_{2} \cdot 2 \mathrm{Al}_{2} \mathrm{O}_{3}+\mathrm{CaO} \rightarrow \mathrm{CaO} \cdot \mathrm{Al}_{2} \mathrm{O}_{3} \cdot 2 \mathrm{SiO}_{2}$

$3 \mathrm{Al}_{2} \mathrm{O}_{3} \cdot 2 \mathrm{SiO}_{2}+3 \mathrm{CaO}+4 \mathrm{SiO}_{2} \rightarrow \mathrm{CaO} \cdot \mathrm{Al}_{2} \mathrm{O}_{3} \cdot 2 \mathrm{SiO}_{2}$

Gehlenite $\left(2 \mathrm{CaO} \cdot \mathrm{Al}_{2} \mathrm{O}_{3} \cdot \mathrm{SiO}_{2}\right)$ could be formed during the latter temperature range due to as follows:

$3 \mathrm{Al}_{2} \mathrm{O}_{3} \cdot 2 \mathrm{SiO}_{2}+\mathrm{CaO} \rightarrow 2 \mathrm{CaO} \cdot \mathrm{Al}_{2} \mathrm{O}_{3} \cdot \mathrm{SiO}_{2}$

Spurrite $\left(2 \mathrm{C}_{2} \mathrm{~S} \cdot \mathrm{CaCO}_{3}\right)$ and wollastonite $\left(\beta-\mathrm{CaO} \cdot \mathrm{SiO}_{2}\right)$ were also produced in this temperature range. The thermal reactions increased in presence of $\mathrm{CaO}, \mathrm{SiO}_{2}, \mathrm{Al}_{2} \mathrm{O}_{3}$ 
and alkalies that were available in the glass waste. Mullite could be reacted with $\mathrm{CaO}$ and $\mathrm{MgO}$ to form cordierite $\left(2 \mathrm{MgO} \cdot 2 \mathrm{Al}_{2} \mathrm{O}_{3} \cdot 5 \mathrm{SiO}_{2}\right)[52]$ as follows:-

$3 \mathrm{Al}_{2} \mathrm{O}_{3} \cdot 2 \mathrm{SiO}_{2}+2 \mathrm{MgO} \rightarrow 2 \mathrm{MgO} \cdot 2 \mathrm{Al}_{2} \mathrm{O}_{3} \cdot 5 \mathrm{SiO}_{2}$

The formation of these new phases combined to those already existing, is an advantage for sintering of glass composite since they displayed the mechanical improvement. Moreover, the collapse or the partial decomposition of other crystalline phases, would favour the abundant viscous flow phase formation, which fill the pore volume, involving a decrease in water absorption and an increase in linear thermal shrinkage $[38,40,49,51,52]$.

\subsubsection{Coefficient of linear thermal expansion}

The calculated coefficients of linear thermal expansion (a) of all batches (G0-G7) are also represented as a function of glass content in Fig. 12 . At $970-975^{\circ} \mathrm{C}$, the line of thermal expansion coefficient of the base batch (G0) was found to be slightly reversed down indicating contraction behaviour. The linear thermal expansion coefficients are stepwise decreased with the increase of glass content comparing with that of the base batch (G0), The obtained (a) of G0 was $7.821 \times 10^{-6}$, which was decreased with increasing the glass content till reach to $5.345 \times 10^{-6}$ with the ceramic batch G7 containing 35\% glass. This is essentially attributed to the low expansion rate of mullite and feldspathic glass that is mainly depending on the ratios of $\mathrm{SiO}_{2}, \mathrm{Al}_{2} \mathrm{O}_{3}$ as well as $\mathrm{Na}_{2} \mathrm{O}$ and $\mathrm{K}_{2} \mathrm{O}[7,9,13]$. It is worth mentioning that the lower value of $(\mathrm{a})$ is in general one of the most valuable features of ceramic products $[15,18,26,29,46]$. So, the prepared ceramic batches containing glass wastes

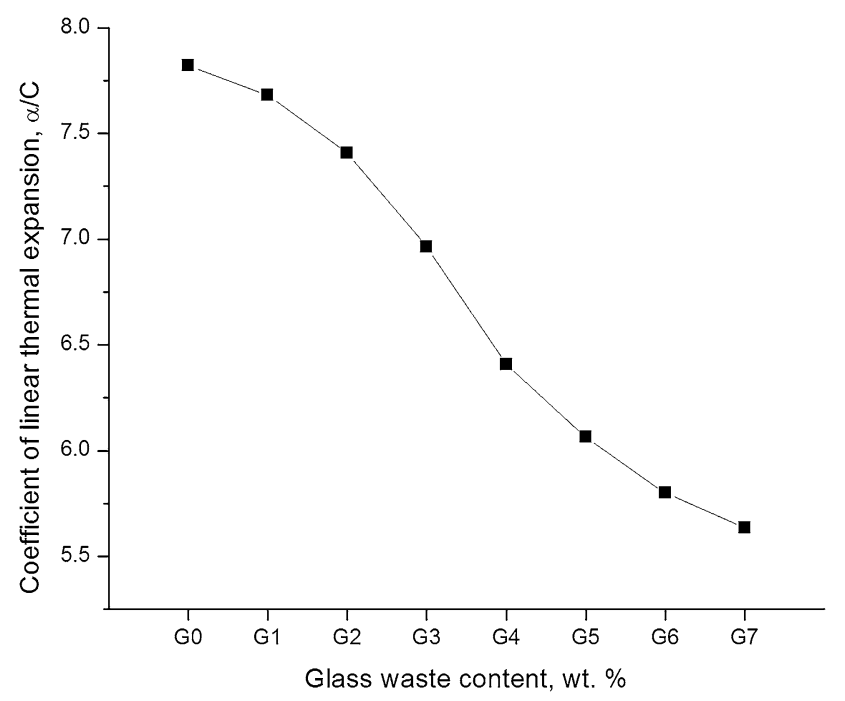

Fig. 12 Coefficeint of linear thermal expansion of the prepared ceramic batches are completely suitable for the production of ceramic products,

\subsection{Color}

The variations in the color of the different samples fired at the temperature range $1000-1200^{\circ} \mathrm{C}$, incorporating several contents of waste glass is varied from pale yellow to pale brown to grayish brown. This variation is probably due to the various thermal reactions between some oxides of the raw materials mainly $\mathrm{SiO}_{2}, \mathrm{Al}_{2} \mathrm{O}_{3}, \mathrm{CaO}, \mathrm{Fe}_{2} \mathrm{O}_{3}, \mathrm{MgO}$, $\mathrm{MnO}$ and $\mathrm{TiO}_{2}$ and those of the glass nanoparticles.

\section{Conclusion}

The main goals of this work was to study the possibility of using waste glass with clay and other ceramic raw materials like feldspar, limestone and quartz for the manufacturing of wall and floor tiles. The main conclusions are:

1. As the firing temperature increased, the water absorption decreased with the increase of glass waste content only up to $25 \mathrm{wt} \%$, and then increased. This was displayed with all firing temperatures. Hence, the fired products with 25 wt $\%$ glass waste showed the lowest water absorption values at all firing temperatures $(6.83,5.35,4.87,3.58,3.15$ and $2.54 \%)$.

2. On the other side, the bulk density increased with increasing of glass waste content and also firing temperature, where the batch incorporated $25 \mathrm{wt} \%$ glass waste exhibited the highest bulk density (2.0011, $2.0127,2.0181,2.0215,2.0226$ and $\left.2.0253 \mathrm{~g} / \mathrm{cm}^{3}\right)$, and then decreased as the firing temperature was furtherly increased with all glass waste contents.

3. 3-The current study also revealed that, the flexural strength of the ceramic products increased and reached a maximum. The highest value was displayed by sample containing $25 \mathrm{wt} \%$ glass waste at all firing temperatures $(10.15,14.47,15.71,19.95,20.0$ and $21.64 \mathrm{MPa}$ ). This prepared batch composition could be used as wall aond floor tiles. Thereby, the optimum waste glass content is $25 \mathrm{wt} \%$, and a temperature of $1200^{\circ} \mathrm{C}$ are recommended to produce wall and floor tiles.

4. The crushing strength of the fired products also increased and to reach its maximum value. The highest value was displayed by sample containing $25 \mathrm{wt} \%$ glass waste (G6) at all firing temperatures $(18.21,26.62$, $27.51,33.65,37.01$ and $38.24 \mathrm{MPa})$. Thereby, the optimum waste glass content of $25 \mathrm{wt} \%$, and a temperature of $1200^{\circ} \mathrm{C}$ are recommended to produce wall and floor tiles. 
5. The dry shrinkage was unchanged, while firing shrinkage was increased with both glass content and firing temperature.

6. The coefficient of linear thermal expansion (a) was stepwise decreased with glass content, i.e. it was in the descending order $7.821 \times 10^{-6}>7.581 \times 10^{-6}>7.4$ $07 \times 10^{-6}>6.963 \times 10^{-6}>6.408 \times 10^{-6}>6.064 \times 10^{-6}>5$. $779 \times 10^{-6}>5.635 \times 10^{-6}$. Accordingly, the lower values of linear thermal expansion coefficients are very suitable for the production of ceramic units.

7. Furthermore, the formation probability of some crystalline phases like gehlenite, spurrite, wollastonite, anorthite, mullite and may be cordierite, is an advantage for sintered glass composite as it exhibited excellent physical and mechanical characteristics. This will discuss in details in Part II.

Acknowledgements Funding was provided by National Research Centre (Grant No. 10060402).

\section{Compliance with ethical standards}

Conflict of interest There is no conflict of interest anywhere.

\section{References}

1. Darweesh HHM (2018) Nanomaterials: classification and properties-part I. J Nanosci 1(1):1-11. https://doi.org/10.31058 /j.nano.2018.11001

2. Darweesh HHM (2018) Nanoceramics: materials, properties, methods and applications-part II. J Nanosci 1(1):40-66. https ://doi.org/10.31058/j.nano.2018.11004

3. Tucci A, Esposito L, Rastelli E, Palmonari C, Rambaldi E (2004) Use of soda lime scrap-glass as a fluxing agent in a porcelain stoneware tile mix. J Eur Ceram Soc 24:83-92

4. Lin KL (2007) Use of thin film transistor liquid crystal display (TFT-LCD) waste glass in the production of ceramic tiles. J Hazard Mater 148:91-97

5. Vieira CMF, Monteiro SN (2009) Incorporation of solid wastes in red ceramics - an updated review. Rev Matér 14:881-905

6. Hojamberdiev M, Eminov A, Xu Y (2011) Utilization of muscovite granite waste in the manufacture of ceramic tiles. Ceram Int 37:871-876

7. Nuttawat K, Jaimasith M, Thiemsorn W (2013) Fabrication of ceramic floor tiles from industrial wastes. Suranaree J Sci Technol 21:65-77

8. Furlanin E, Maschio S (2013) Mechanical properties and microstructure of fast fired tiles made with blends of kaolin and olivine powders. Ceram Int 39:9391-9396

9. Kim K, Kim K, Hwang J (2016) Characterization of ceramic tiles containing LCD waste glass. Ceram Int 42:7626-7631

10. Ke S, Wang Y, Pan Z, Ning C, Zheng S (2016) Recycling of polished tile waste as a main raw material in porcelain tiles. J Clean Prod 115:238-244

11. Amin SK, Sibak HA, El-Sherbiny SA, Abadir MF (2016) An overview of ceramic wastes management in construction. Int J Appl Eng 11:2680-2685

\section{SN Applied Sciences}

12. Amin SK, Abdel-Hamid EM, El-Sherbiny SA, Sibak HA, Abadir MF (2017) The use of sewage sludge in the production of ceramic floor tiles. HBRC J 14:309-315

13. Sahar MR, Hamzah K, Rohani MS (2011) The microstructural study of cullet-clay ceramics. Phys Procedia 22:125-129

14. Kourti I, Cheeseman CR (2010) Properties and microstructure of lightweight aggregate produced from lignite coal fly ash and recycled glass. Resour Conserv Recycl 54:769-775

15. Sonjida M, Ahsan M, Hamid A, Ahmed S (2011) Effect of waste glass powder on physico-mechanical properties of ceramic tiles. Bangladesh J Sci Res 24:169-180

16. Youssef NF, Abadir MF, Shater MAO (1998) Utilization of soda glass (cullet) in the manufacture of wall and floor tiles. J Eur Ceram Soc 18:1721-1727

17. Bragança SR, Bergmann CP (2004) Traditional and glass powder porcelain: technical and microstructure analysis. J Eur Ceram Soc 24:2383-2388

18. Pontikes Y, Esposito L, Tucci A, Angelopoulos GN (2007) Thermal behaviour of clays for traditional ceramics with soda-limesilica waste glass mixture. J Eur Ceram Soc 27:1657-1663

19. Vorrada L, Panyachai T, Kaewsimork K, Siritai C (2009) Effects of recycled glass substitution on the physical and mechanical properties of clay bricks. Waste Manag (Oxf) 29:2717-2721

20. Nicoletta M, D'Alessio D, Diella V, Pavece A (2013) Effects of soda-lime-silicate waste glass on mullite formation kinetics and microstructures development in vitreous ceramics. J Environ Manag 124:100-107

21. Jariah M, Arudra D, Zulkifli MR (2013) Microstructural properties of glass composite material made from incinerated scheduled waste slag and soda lime silica (SLS) waste glass. J Non-cryst Solids 367:8-13

22. ASTM Specification C373-72 (1972) Standard test method for water absorption, bulk density, apparent porosity and specific gravity of white ware products. Part 17:159-167, reapproved 1980:308-309

23. Darweesh HHM (2015) Ceramic wall and floor tiles containing local waste of cement kiln dust-part I: densification parameters. Am J Civ Eng Archit 2(5):35-43

24. ASTM Specification C674-71 (1971) Standard test method for flexural properties of ceramic whiteware products. Part 17:668-671

25. ASTM Designation, C78-02 (2002) Standard test method for flexural strength of concrete using simple beam with threepoints loading system, pp 1-3

26. Darweesh HHM (2016) Ceramic wall and floor tiles containing local waste of cement kiln dust-part II: dry and firing shrinkage as well as mechanical properties. Am J Civ Eng Archit 4(2):44-49. https://doi.org/10.12691/ajcea-4-2-1

27. ASTM Specification C170-90 (1990) Standard test method for cold crushing strength of dimensional stones, pp 828-830

28. ASTM Specification C326-32 (1976) Standard test method for shrinkage of ceramic whitewares after drying and firing. Part 17:266-267

29. Luz AP, Ribeiro S (2007) Use of glass waste as a raw material in porcelain stoneware tile mixtures. Ceram Int 33:761-765

30. Matteucci F, Dondi M, Guarini G (2002) Effect of soda-lime glass on sintering and technological properties of porcelain stoneware tiles. Ceram Int 28:873-880

31. Duran P, Tarjat J, Moure C (2003) Sintering behavior and microstructural evolution of agglomerated spherical particles of high-purity barium titanate. Ceram Int 29:419-425

32. Phonphuak N, Kanyakam S, Chindaprasirt P (2016) Utilization of waste glass to enhance physical mechanical properties of fired clay brick. J Clean Prod 112:3057-3062 
33. Monterio RC, Lima MM (2003) Effect of compaction on the sintering of borosilicate glass/alumina composites. J Eur Ceram Soc 23:1813-1818. https://doi.org/10.1016/S0955-2219(02)00422-3

34. Lima MM, Monterio RCC (2001) Characterization and thermal behavior of a borosilicate glass. Thermochim Acta 373:69-74. https://doi.org/10.1016/S0040-6031(01)00456-7

35. Chen GH, Xin-Yu L (2006) Low-temperature-sintering and characterization of glass-ceramic composites. J Mater Sci: Mater Electron 17:877-882. https://doi.org/10.1007/s10854-006-0039-7

36. Rayan W, Radford C (1987) Whitewares production, testing and quality control, 1st edn. Institute of Ceramics, Pergamon Press, Oxford, pp 200-203

37. Ibanez A, Pena P, Sandoval F, Gonzalez JM (1992) Modification of the inert component in wall bodies. Am Ceram Soc Bull 71:1661-1668

38. Darweesh HHM, Wahsh MMS, Negim EM (2012) Densification and thermo mechanical properties of conventional ceramic composites containing two different industrial byproducts. Am Eurasian J Sci Res 7:123-130. https://doi.org/10.5829/idosi.aejsr .2012.7.3.1104

39. Kitouni S, Harabi A (2011) Sintering and mechanical properties of porcelains prepared from Algerian raw materials. Cerâmica $57: 453-460$

40. Kale SA (2019) Mechanical design, materials and manufacturing, chapter 7 by Darweesh HHM (2019) “Nanomaterials, ceramic bulk and bioceramics: synthesis, properties and applications", 1st edn. Nova Science, New York, pp 175-262

41. Darweesh HHM (2015) Ceramic wall and floor tiles containing local waste of cement kiln dust-part I: densification parameters. Am J Environ Eng Sci 2(5):35-43

42. Darweesh HHM (2016) Ceramic wall and floor tiles containing local waste of cement kiln dust-part II: dry and firing shrinkage as well as mechanical properties. Am J Civ Eng Archit 4(2):44-49. https://doi.org/10.12691/ajcea-4-2-1

43. Costa FB, Teixeira SR, Souza AE, Santos GTA (2009) Recycling of glass cullet as aggregate for clays used to produce roof tiles. Rev Matér 14:1146-1153
44. Martín-Márquez J, Ma Rincón J, Romero M (2008) Effect of firing temperature on sintering of porcelain stoneware tiles. Ceram Int 34:1867-1873

45. Martín-Márquez J, De la Torre AG, Aranda MAG, Rincón JM, Romero M (2009) Evolution with temperature of crystalline and amorphous phases in porcelain stoneware. J Am Ceram Soc 92:229-234

46. Martín-Márquez J, Rincón JM, Romero M (2010) Effect of microstructure on mechanical properties of porcelain stoneware. $J$ Eur Ceram Soc 30:3063-3069

47. Leonelli $C$, Bondioli $F$, Veronesi $P$, Romagnoli M, Manfredini $T$, Pellacani GC, Cannillo V (2001) Enhancing the mechanical properties of porcelain stoneware tiles: a microstructural approach. J Eur Ceram Soc 21:785-793

48. Abadir MF, Sallam EH, Bakr IM (2002) Preparation of porcelain tiles from Egyptian raw materials. Ceram Int 28:303-310

49. Zanelli C, Raimondo M, Guarini G, Dondi M (2011) The vitreous phase of porcelain stoneware: Composition, evolution during sintering and physical properties. J Non-Cryst Solids 357:3251-3260

50. Tucci A, Esposito L, Malmusi L, Rambaldi E (2007) New body mixes for porcelain stoneware tiles with improved mechanical characteristics. J Eur Ceram Soc 27:1875-1881

51. Rayan W (1978) Properties of ceramic raw materials, 2nd edn. Pergamon Press, Oxford

52. Konta J (1981) Properties of ceramic raw materials, ceramic monograph 1.1.4. Verlag Schmid GmbH, Freiburg

53. Jackson G (1969) Introduction to whitewares, 1st edn. Elsevier, Amsterdam

54. Lee $W E$, Iqbal $Y$ (2001) Influence of mixing on mullite formation in porcelain. J Eur Ceram Soc 21:2583-2586

Publisher's Note Springer Nature remains neutral with regard to jurisdictional claims in published maps and institutional affiliations. 